\title{
Expression and prognostic significance of melatonin receptor MT1 in patients with gastric adenocarcinoma
}

\author{
X. T. WANG ${ }^{1, *}$, C. W. CHEN ${ }^{1,2, \sharp}$, X. M. ZHENG ${ }^{1}$, B. WANG ${ }^{1}$, S. X. ZHANG ${ }^{3}$, M. H. YAO ${ }^{4}$, H. CHEN ${ }^{4}$, H. F. HUANG ${ }^{1, *}$ \\ ${ }^{1}$ Central Laboratory, Fujian Medical University Union Hospital, Fujian Medical University, Fuzhou, China; ${ }^{2}$ Department of Clinical Laboratory, \\ The Hospital of Nanan City, Nanan, China; ${ }^{3}$ Fujian Institute of Hematology, Fujian Provincial Key Laboratory on Hematology, Fujian Medical \\ University Union Hospital, Fuzhou, China; ${ }^{4}$ Department of Pathology, Fujian Medical University Union Hospital, Fujian Medical University, \\ Fuzhou, China
}

${ }^{*}$ Correspondence: Huanghuif@126.com

${ }^{*}$ Contributed equally to this work.

Received February 20, 2019 / Accepted August 11, 2019

\begin{abstract}
Melatonin receptor type 1 (MTNR1A or MT1) is known to play an important role in cancer progression; however, its prognostic value for resected gastric adenocarcinoma (RGA) is unknown. In this study, we examined the potential of MT1 as a prognostic biomarker for RGA. The expression of the MT1 was evaluated in 67 patients with RGA by immunohistochemistry, and the relationship between MT1 levels and RGA prognosis was analyzed by Chi-square test, multivariate Cox regression, Kaplan-Meier method, and log-rank test. High MT1 expression was associated with a poor survival rate (29.0\%, $\mathrm{p}=0.002)$ and the occurrence of metastasis $(62.9 \%, \mathrm{p}=0.004)$. Kaplan-Meier survival analysis and log rank tests revealed that patients with high expression of the MT1 had significantly shorter median overall survival compared to those with low expression (33.0 vs. 65.0 months, respectively; $\mathrm{p}=0.02$ ). Multivariate Cox analysis indicated that the calculated death risk (hazard ratio [HR]) in patients with high expression levels of the MT1 increased to 2.68 (95\% confidence interval [CI] 1.21-5.94, $\mathrm{p}=0.015)$, which was higher compared to those with low levels. HR of death was also high in patients with advanced T stage (2.51; $95 \%$ CI 1.00-6.26, $\mathrm{p}=0.049)$ and metastasis (5.02; 95\% CI 1.94-13.03, p=0.001). Our results showed that high MT1 expression in primary gastric adenocarcinoma tissues was associated with the occurrence of metastasis and poor prognosis. It may have prognostic significance as a potential biomarker in patients with RGA.
\end{abstract}

Key words: melatonin receptor, resected gastric adenocarcinoma, immunohistochemistry, prognosis, metastasis

Gastric cancer is one of the most common digestive tract malignancies worldwide [1], and gastric adenocarcinoma (GA) represents over $90 \%$ of gastric tumors. Surgery combined with postoperative chemotherapy is still the most effective method for treating resectable GA (RGA), but the prognosis remains grim in patients with late-stage cancer. Therefore, early detection and timely treatment are particularly important for increasing the survival rate. In this regard, molecular prognostic biomarkers specific for early-stage GA are of great clinical value, as they can direct therapeutic approaches and, ultimately, extend patient's survival [2].

Melatonin is a hormone produced mainly in the pineal gland as well as in the gastrointestinal tract, retina, skin, bone marrow, and reproductive organs [3-5]. Enterochromaffin cells of the gastrointestinal mucosa are the main source of melatonin outside the pineal gland [6], and a previous study suggested that melatonin could affect the function of the gastrointestinal epithelium and smooth muscles as well as of lymphatic tissues of the immune system [7]. Furthermore, it has been shown that melatonin can inhibit the growth of gastric tumors through its immunomodulatory and antioxidant activities, stimulation of apoptosis, and inhibition of angiogenesis $[8,9]$.

The pleiotropic effects of melatonin are mediated by both receptor-independent and receptor-dependent mechanisms [10-12]. Melatonin-specific membrane receptors belong to the G-protein-coupled receptor superfamily $[13,14]$ and there are two main types of such receptors in humans: MT1 and MT2 (formerly known as MTNR1A and MTNR1B, respectively), which have distinct molecular and functional characteristics $[15,16]$. Thus, MT1 is involved in reproduction, metabolism, vasoconstriction, and tumor cell proliferation, whereas MT2 regulates circadian rhythm, vasodilation, and immune responses [17-19]. Activation of MT1 in tumor cells was shown to reduce the production of cyclic 
adenosine monophosphate (cAMP), leading to downregulation of protein kinase A (PKA) and decrease in phosphorylation-dependent activation of cAMP response elementbinding (CREB) transcription factor [20], which suppressed the growth of cancer cells. Thus, an in vitro study indicated that melatonin reduced the proliferation and viability of HepG2 cells by activating p38, ERK, and JNK protein kinases through MT1 receptor [12]. Another study revealed that melatonin-MT1 signaling was involved in suppression of breast cancer cell invasion, possibly through downregulation of the p38 pathway and inhibition of the expression and activity of metalloproteinases MMP-2 and MMP-9 [21]. Importantly, Nasrabadi et al. [22, 23] found that the mRNA expression of MT1 and MT2 in tumors and marginal cancer tissues was increased in GA patients compared with healthy individuals; however, these studies did not evaluate MT1 and MT2 protein expression in GA.

Given the expression of MT1 in the gastrointestinal tract and anticancer effects of melatonin-MT1 signaling, we hypothesized that MT1 levels in RGA may predict patient's outcome. Therefore, the aim of this study was to examine MT1 expression in RGA and evaluate its potential as an early-stage cancer biomarker for patients with RGA.

Table 1. Patients' characteristics.

\begin{tabular}{|c|c|c|}
\hline \multirow{2}{*}{ Variable } & \multicolumn{2}{|c|}{ Cases $(n=67)$} \\
\hline & $\mathrm{n}$ & $\%$ \\
\hline \multicolumn{3}{|l|}{ Age } \\
\hline$<60$ & 34 & 50.7 \\
\hline$\geq 60$ & 33 & 49.3 \\
\hline \multicolumn{3}{|l|}{ Gender } \\
\hline Male & 47 & 70.1 \\
\hline Female & 20 & 29.9 \\
\hline \multicolumn{3}{|l|}{ Gross findings } \\
\hline Apophysis & 12 & 17.9 \\
\hline Invasion & 55 & 82.1 \\
\hline \multicolumn{3}{|l|}{ Tumor site } \\
\hline Proximal/Mid & 31 & 46.3 \\
\hline Distal & 36 & 53.7 \\
\hline \multicolumn{3}{|c|}{ Lymph node metastasis } \\
\hline No metastasis & 32 & 47.8 \\
\hline Metastasis & 35 & 52.2 \\
\hline \multicolumn{3}{|l|}{ T stage } \\
\hline $\mathrm{T} 1+\mathrm{T} 2$ & 24 & 35.8 \\
\hline $\mathrm{T} 3+\mathrm{T} 4$ & 43 & 64.2 \\
\hline \multicolumn{3}{|l|}{ Survival } \\
\hline Alive & 33 & 49.3 \\
\hline Dead & 34 & 50.7 \\
\hline \multicolumn{3}{|l|}{ MT1 expression } \\
\hline Low & 36 & 53.7 \\
\hline High & 31 & 46.3 \\
\hline
\end{tabular}

\section{Patients and methods}

Patients. This retrospective study involved 67 patients with the pathological diagnosis of primary GA, who underwent surgery between 2006 and 2009 at the Fujian Medical University Union Hospital (Fuzhou, China). The patients had no additional cancers, such as osteosarcoma, breast cancer, or other diseases accompanied by high expression of the MT1; they were followed up every six months, beginning at three months after operation until December 2014. Clinical data, including age, gender, tumor site, gross findings, $\mathrm{T}$ stage, and lymph node metastasis were obtained from detailed electronic medical records. The tumor tissues were taken from the resected primary tumors and the survival data were collected through telephone and the Social Security Death Index. This research was approved by the Ethics Committee of Fujian Medical University Union Hospital (2018KY062).

Immunohistochemistry. The expression of the MT1 was analyzed in paraffin-embedded RGA tissues by immunohistochemistry (IHC) using a rabbit anti-human MT1 polyclonal antibody (1:100 dilution; CUSABIO, Wuhan, China) as described in our previous study [24]. The immunohistochemical staining results were assigned a mean score taking into account both the intensity of staining and the proportion of tumor cells with an unequivocal positive reaction. Each section was independently assessed by two pathologists blind to the clinical information in the experiment. The results were scored as $0,1,2$, and 3 based on staining intensity and scope: scores 0 or 1 were regarded as low expression and 2 or 3 as high expression of the MT1 [25].

Statistical analysis. The experimental data were analyzed using the SPSS17.0 software (SPSS Inc., Chicago, IL, USA). Chi-square test was performed to determine the association of MT1 receptor expression with clinicopathological features and prognosis of patients. The correlation between MT1 expression and patient survival was further evaluated by univariate and multivariate Cox regression analysis, KaplanMeier estimator, and log-rank test. In addition, the multivariate Cox regression model was adjusted for age, gender, tumor site, gross findings, $T$ stage, and lymph node metastasis. All tests were two-sided, and $\mathrm{p}<0.05$ was considered as statistically significant.

\section{Results}

Patient characteristics. The characteristics and clinical information for the 67 patients with primary GA were shown in Table 1 . There were 47 men $(70.1 \%)$ and 20 women (29.9\%); 34 patients were $<60$ years old, and 33 were $\geq 60$ years old (median, 59 years; range, $37.0-88.0$ years). Among the patients, $24(35.8 \%)$ had T1 or T2 stages and $43(64.2 \%)$ had T3 or T4 stages. Thirty-four patients $(50.7 \%)$ died during the follow-up period; the median follow-up time was 57 months and the median overall survival was 60 months (range, 2.0-104.0 months). 
Relationship between MT1 expression and clinical characteristics. Among the 67 RGA tissue specimens examined by IHC, 31 (46.3\%) had high MT1 expression (Table 1). As shown in Table 2, MT1 levels were significantly associated with metastasis $(p=0.04)$ and patient survival $(\mathrm{p}=0.002)$. Thus, among 35 patients with metastasis and 22 patients with shorter survival, the percentage of those with high MT1 expression in RGA increased to $62.9 \%$ and $64.7 \%$, respectively. There was no significant association between MT1 expression and other clinicopathological factors, including age, gender, tumor site, gross findings, and T stage (Table 2). Representative IHC results for tissues with low and high MT1 levels are shown in Figure 1.

Association of MT1 expression with survival. Data analysis with Chi-square tests indicated that high MT1 expression was significantly associated with a poorer survival rate $(29.0 \%, p=0.002$ ) (Table 3 ). Decreased survival was also correlated with advanced $\mathrm{T}$ stage $(37.2 \%, \mathrm{p}=0.008)$ and metastasis $(20.0 \%, \mathrm{p}<0.001)$. Kaplan-Meier survival curves and log-rank tests also indicated that patients with high MT1 levels had significantly shorter median overall survival compared to those with low MT1 levels (33.0 vs. 65.0 months, respectively; $\mathrm{p}=0.02$, Figure 2 ). Then we further performed the stratified analysis according to metastasis (Figure 3), we found that patients with high expression of MT1 exhibited a shorter survival time (48.0 vs. 70.0 months, $\mathrm{p}=0.01$ ) in non-metastatic patients (Figure 3A); while in the metastatic patients, no significant relevance was found between MT1 expression and survival time (Figure 3B). Univariate and multivariate Cox regression analyses confirmed these results by showing that positive lymph node metastasis, advanced $\mathrm{T}$ stage, and high MT1 expression were significantly associated with an increased risk of death (Table 4). Thus, the calculated death risk (hazard ratio [HR]) in patients with high MT1 expression increased to 2.68 (95\%, confidence interval [CI] 1.21-5.94, $\mathrm{p}=0.015)$, which was higher compared to that of patients with low MT1 expression. The HR of death was also elevated in patients with advanced $\mathrm{T}$ stage and metastasis to 2.51 (95\%, CI 1.00-6.26, p=0.049) and 5.04 (95\%, CI $1.94-13.03, \mathrm{p}=0.001)$, respectively.

\section{Discussion}

The purpose of this study was to investigate MT1 expression, its relationship with clinicopathological characteristics of patients with primary GA, and the potential of MT1 as a biomarker for early-stage GA. Previous studies have confirmed that both MT1 and MT2 are involved in the anticancer effect of melatonin, suggesting that melatonin or melatonin receptor agonists may be used in the treatment of cancer [4, 26]. Nasrabadi et al. [23] demonstrated that MT1 levels were increased in tumor and non-tumor (marginal) tissues of GA patients compared with those in healthy individuals and suggested that the observed upregulation of MT1 surface expression represented a defense mechanism
Table 2. Association between MT1 expression and characteristics of patients.

\begin{tabular}{|c|c|c|c|}
\hline \multirow{2}{*}{ Characteristics } & \multicolumn{2}{|c|}{ MT1 expression } & \multirow{2}{*}{ p-value } \\
\hline & Low (\%) & High (\%) & \\
\hline \multicolumn{4}{|l|}{ Age } \\
\hline$<60$ & $19(55.9)$ & $15(44.1)$ & \multirow{2}{*}{0.720} \\
\hline$\geq 60$ & $17(51.5)$ & $16(48.5)$ & \\
\hline \multicolumn{4}{|l|}{ Gender } \\
\hline Male & $24(51.1)$ & $23(48.9)$ & \multirow{2}{*}{0.502} \\
\hline Female & $12(60.0)$ & $8(40.0)$ & \\
\hline \multicolumn{4}{|l|}{ Gross findings } \\
\hline Apophysis & $7(58.3)$ & $5(41.7)$ & \multirow{2}{*}{0.724} \\
\hline Invasion & $29(52.7)$ & $26(47.3)$ & \\
\hline \multicolumn{4}{|l|}{ Tumor site } \\
\hline Proximal/Mid & $15(48.4)$ & $16(51.6)$ & \multirow{2}{*}{0.416} \\
\hline Distal & $21(58.3)$ & $15(41.7)$ & \\
\hline \multicolumn{4}{|c|}{ Lymph node metastasis } \\
\hline No metastasis & $23(71.9)$ & $9(28.1)$ & \multirow{2}{*}{$\mathbf{0 . 0 0 4}^{*}$} \\
\hline Metastasis & $13(37.1)$ & $22(62.9)$ & \\
\hline \multicolumn{4}{|l|}{ T stage } \\
\hline $\mathrm{T} 1+\mathrm{T} 2$ & $12(50.0)$ & $12(50.0)$ & \multirow{2}{*}{0.647} \\
\hline $\mathrm{T} 3+\mathrm{T} 4$ & $24(55.8)$ & $19(44.2)$ & \\
\hline \multicolumn{4}{|l|}{ Survival } \\
\hline Alive & $24(72.7)$ & $9(27.3)$ & \multirow{2}{*}{$0.002^{\star}$} \\
\hline Dead & $12(35.3)$ & $22(64.7)$ & \\
\hline
\end{tabular}

${ }^{*}$ Statistically significant $(\mathrm{p}<0.05)$. MT1, melatonin receptor type 1

Table 3. Association between survival and characteristics of patients

\begin{tabular}{|c|c|c|c|}
\hline \multirow{2}{*}{ Characteristics } & \multicolumn{2}{|c|}{ Survival } & \multirow{2}{*}{ p-value } \\
\hline & Alive (\%) & Deceased \%) & \\
\hline \multicolumn{4}{|l|}{ Age } \\
\hline$<60$ & $18(52.9)$ & $16(47.1)$ & \multirow{2}{*}{0.540} \\
\hline$\geq 60$ & $15(45.5)$ & $18(54.5)$ & \\
\hline \multicolumn{4}{|l|}{ Gender } \\
\hline Male & $24(51.1)$ & $23(48.9)$ & \multirow{2}{*}{0.650} \\
\hline Female & $9(45.0)$ & $11(55.0)$ & \\
\hline \multicolumn{4}{|l|}{ Gross findings } \\
\hline Apophysis & $7(58.3)$ & $5(41.7)$ & \multirow{2}{*}{0.487} \\
\hline Invasion & $26(47.3)$ & $29(52.7)$ & \\
\hline \multicolumn{4}{|l|}{ Tumor site } \\
\hline Proximal/Mid & $15(48.4)$ & $16(51.6)$ & \multirow{2}{*}{0.895} \\
\hline Distal & $18(50.0)$ & $18(50.0)$ & \\
\hline \multicolumn{4}{|c|}{ Lymph node metastasis } \\
\hline No metastasis & $26(81.3)$ & $6(18.7)$ & \multirow{2}{*}{$\underset{0.001^{\star}}{<}$} \\
\hline Metastasis & $7(20.0)$ & $28(80.0)$ & \\
\hline \multicolumn{4}{|l|}{ T stage } \\
\hline $\mathrm{T} 1+\mathrm{T} 2$ & $17(70.8)$ & $7(29.2)$ & \multirow{2}{*}{$0.008^{\star}$} \\
\hline $\mathrm{T} 3+\mathrm{T} 4$ & $16(37.2)$ & $27(62.8)$ & \\
\hline \multicolumn{4}{|l|}{ MT1 expression } \\
\hline Low & $24(66.7)$ & $12(33.3)$ & \multirow{2}{*}{$0.002^{*}$} \\
\hline High & $9(29.0)$ & $22(71.0)$ & \\
\hline
\end{tabular}

${ }^{*}$ Statistically significant $(\mathrm{p}<0.05)$. MT1, melatonin receptor type 1 


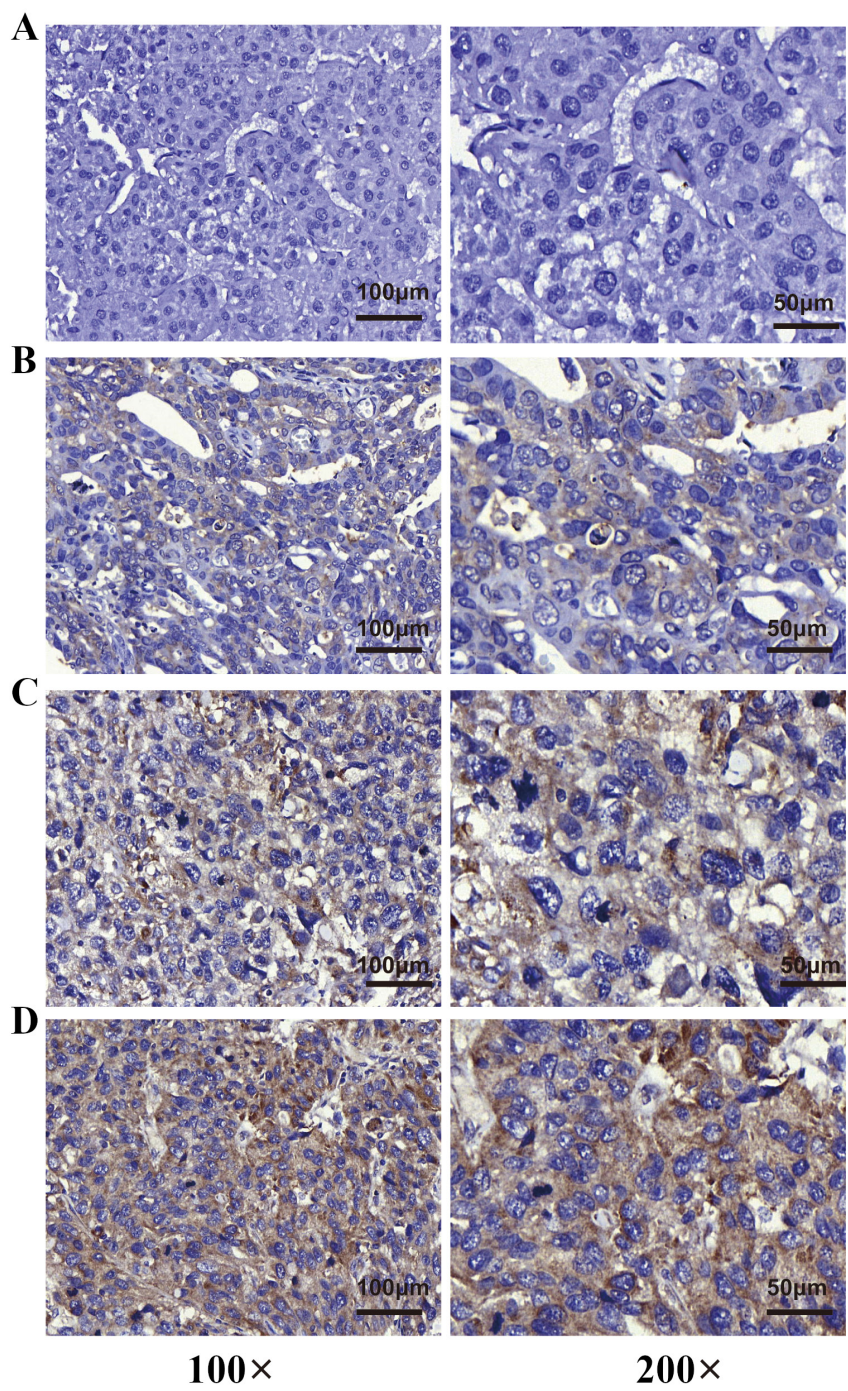

Figure 1. Representative images of MT1 staining in resected gastric adenocarcinoma (RGA). RGA tissue specimens were analyzed by IHC using anti-MT1 antibody and scored according to MT1 staining intensity. A) score ' 0 ' for MT1 staining in RGA tissues; B) score ' 1 ' for MT1 staining in RGA tissues; C) score ' 2 ' for MT1 staining in RGA tissues; D) score ' 3 ' for MT1 staining in RGA tissues.

in response to a decrease of melatonin concentration in surrounding tissues. Furthermore, their results indicated that melatonin, through the MT1 receptor, could play a preventive role in GA, especially for patients over 50 years old.

Our current study revealed that high expression of the MT1 was associated with poor prognosis and the occurrence of metastasis in patients with primary GA but did not show significant correlation with other clinicopathological factors. These findings indicated that high levels of MT1 expression were correlated with gastric cancer aggressiveness, which may be linked to tumor cell proliferation [17]. It is known that the secretion of melatonin in healthy people gradually decreases with age [27] and negatively correlates with the expression of the MT1 [28]. Furthermore, serum melatonin
Table 4. Univariate and multivariate Cox regression analyses for overall survival in patients

\begin{tabular}{|c|c|c|c|c|}
\hline \multirow{2}{*}{ Characteristics } & \multicolumn{2}{|c|}{ Univariate analysis } & \multicolumn{2}{|c|}{ Multivariate analysis } \\
\hline & HR (95\% CI) & p-value & HR (95\% CI) & p-value \\
\hline \multicolumn{5}{|l|}{ Age } \\
\hline$<60$ & 1.00 & \multirow{2}{*}{0.254} & 1.00 & \multirow{2}{*}{0.063} \\
\hline$\geq 60$ & $1.49(0.75-2.96)$ & & $2.01(0.96-4.18)$ & \\
\hline \multicolumn{5}{|l|}{ Gender } \\
\hline Male & 1.00 & \multirow{2}{*}{0.485} & 1.00 & \multirow{2}{*}{0.107} \\
\hline Female & $1.30(0.63-2.67)$ & & $1.94(0.87-4.35)$ & \\
\hline \multicolumn{5}{|l|}{ Gross findings } \\
\hline Apophysis & 1.00 & \multirow{2}{*}{0.651} & 1.00 & \multirow{2}{*}{0.736} \\
\hline Invasion & $1.25(0.48-3.23)$ & & $1.18(0.45-3.10)$ & \\
\hline \multicolumn{5}{|l|}{ Tumor site } \\
\hline Proximal/Mid & 1.00 & \multirow{2}{*}{0.922} & 1.00 & \multirow{2}{*}{0.473} \\
\hline Distal & $1.03(0.53-2.03)$ & & $0.76(0.36-1.60)$ & \\
\hline \multicolumn{5}{|l|}{$\begin{array}{l}\text { Lymph node } \\
\text { metastasis }\end{array}$} \\
\hline No metastasis & 1.00 & \multirow[b]{2}{*}{$<0.001^{\star}$} & 1.00 & \multirow{2}{*}{$0.001^{\star}$} \\
\hline Metastasis & $6.60(2.71-16.09)$ & & $5.02(1.94-13.03)$ & \\
\hline \multicolumn{5}{|l|}{ T stage } \\
\hline $\mathrm{T} 1+\mathrm{T} 2$ & 1.00 & \multirow{2}{*}{$0.018^{\star}$} & 1.00 & \multirow{2}{*}{$0.049^{*}$} \\
\hline $\mathrm{T} 3+\mathrm{T} 4$ & $2.75(1.20-6.37)$ & & $2.51(1.00-6.26)$ & \\
\hline \multicolumn{5}{|l|}{ MT1 expression } \\
\hline Low & 1.00 & \multirow{2}{*}{$\mathbf{0 . 0 0 3}^{*}$} & 1.00 & \multirow{2}{*}{$0.015^{\star}$} \\
\hline High & $2.91(1.43-5.94)$ & & $2.68(1.21-5.94)$ & \\
\hline
\end{tabular}

${ }^{*}$ Statistically significant $(\mathrm{p}<0.05)$. HR, hazard ratio; CI, confidence interval; MT1, melatonin receptor type 1 .

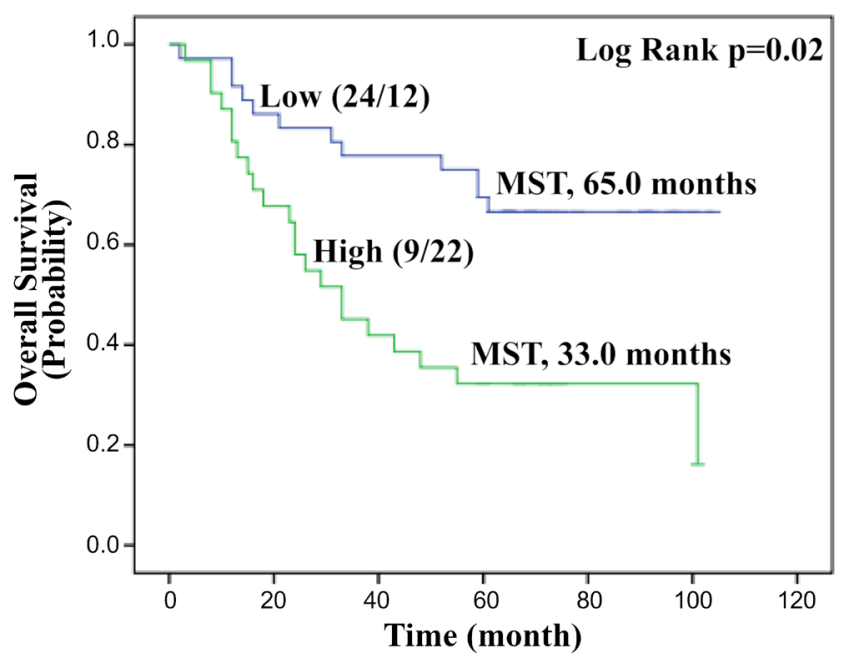

Figure 2. Kaplan-Meier curves according to MT1 expression levels in RGA samples of 67 patients. MST, median survival time (months); $\mathrm{p}=\mathbf{0 . 0 2}$ by log-rank test.

levels were found to be significantly lower in ovarian cancer patients compared to those in healthy women [28]. Therefore, the correlation of high MT1 expression with poor prognosis observed in this study may be because the level of melatonin in patients with tumor metastasis was extremely low, and 
A

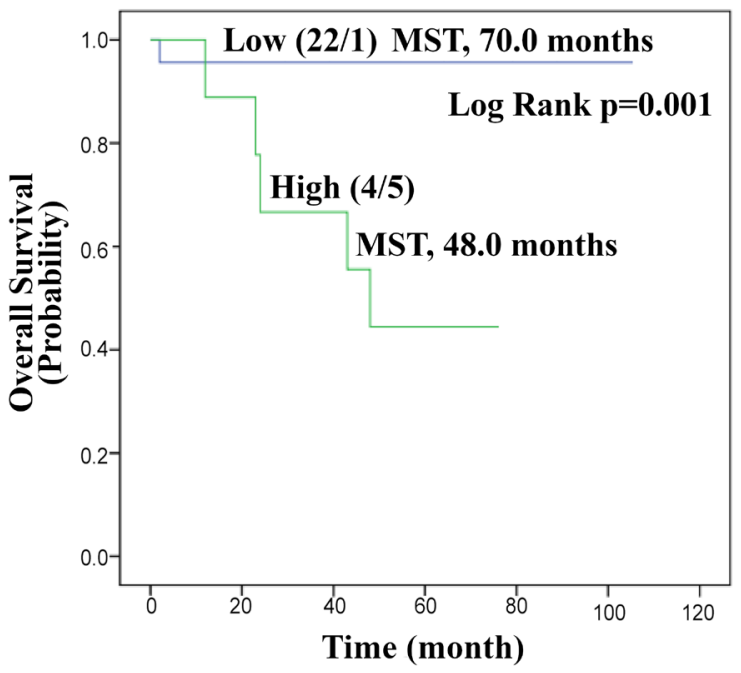

B

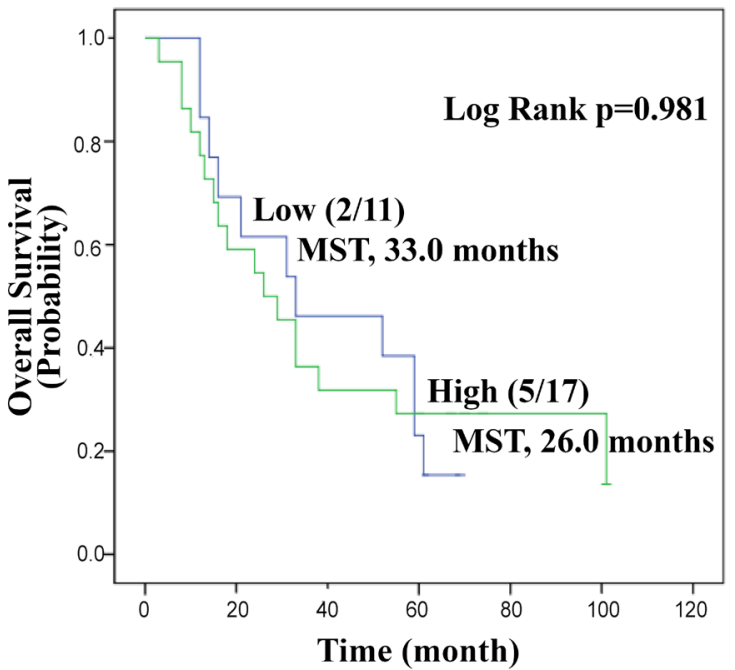

Figure 3. The stratified analysis according to metastasis in RGA samples of 67 patients. A) Kaplan-Meier curves according to MT1 receptor expression levels without metastasis patients; B) Kaplan-Meier curves according to MT1 receptor expression levels with metastasis patients. MST, median survival time (months).

the feedback caused the increase of MT1, which leaded to excessive accumulation of MT1 on the membrane of GA cells. This hypothesis provides a basis for clinical research on the application of exogenous melatonin in the treatment of gastric cancer. Hence, a previous clinical study has already shown that GA patients receiving combination treatment with chemotherapeutic drugs and melatonin had significantly higher rates of overall tumor regression and 2-extrayear survival than those receiving chemotherapy alone [29].

In conclusion, this is the first study to demonstrate that high MT1 expression in primary GA tissues was related to the occurrence of metastasis and poor prognosis, as indicated by shorter survival time and increased death risk. Our results suggest that the expression of the MT1 can be a candidate for independent prognostic biomarker in patients with RGA.

Acknowledgements: This work was supported by National Natural Science Foundation of China, (grant number: 81870108), Fujian Province Natural Fund, (grant number: 2019J01460), Fujian Medicine Innovation Program, (grant number: 2018-CX-18), Joint Funds for the innovation of science and technology, Fujian province,(grant number: 2017Y9053), Government-funded Project of the Construction of Highlevel Laboratory, (Min2017 No.4 File), Construction Project of Fujian Medical Center of Hematology, (Min201704), National and Fujian Provincial Key Clinical Specialty Discipline Construction Program.

\section{References}

[1] BRAY F, REN JS, MASUYER E, FERLAY J. Global estimates of cancer prevalence for 27 sites in the adult population in 2008. Int J Cancer 2013; 132: 1133-1145. https://doi. org/10.1002/ijc.27711
[2] ANDREWS J, YEH P, PAO W, HORN L. Molecular predictors of response to chemotherapy in non-small cell lung cancer. Cancer J 2011; 17: 104-113. https://doi.org/10.1097/ PPO.0b013e318213f3cf

[3] PARKIN DM, BRAY FI, DEVESA SS. Cancer burden in the year 2000. The global picture. Eur J Cancer 2001; 37 Suppl 8: S4-66. https://doi.org/10.1016/s0959-8049(01)00267-2

[4] PANDI-PERUMAL SR, TRAKHT I, SRINIVASAN V, SPENCE DW, MAESTRONI GJ et al. Physiological effects of melatonin: role of melatonin receptors and signal transduction pathways. Prog Neurobiol 2008; 85: 335-353. https:// doi.org/10.1016/j.pneurobio.2008.04.001

[5] STEFULJ J, HORTNER M, GHOSH M, SCHAUENSTEIN $\mathrm{K}$, RINNER I et al. Gene expression of the key enzymes of melatonin synthesis in extrapineal tissues of the rat. J Pineal Res 2001; 30: 243-247. https://doi.org/10.1034/j.1600079x.2001.300408.x

[6] HUETHER G. Melatonin synthesis in the gastrointestinal tract and the impact of nutritional factors on circulating melatonin. Ann N Y Acad Sci U S A 1994; 719: 146-158. https://doi.org/10.1111/j.1749-6632.1994.tb56826.x

[7] Coughlin CC, Finck BN, Eagon JC, et al. Effect of marked weight loss on adiponectin gene expression and plasma concentrations. Obesity (Silver Spring). 2007; 15(3): 640-5.

[8] WANG RX, LIU H, XU L, ZHANG H, ZHOU RX. Melatonin downregulates nuclear receptor RZR/RORgamma expression causing growth-inhibitory and anti-angiogenesis activity in human gastric cancer cells in vitro and in vivo. Oncol Lett 2016; 12: 897-903. https://doi.org/10.3892/ ol.2016.4729

[9] LIU H, XU L, WEI JE, XIE MR, WANG SE et al. Role of CD4+ CD25+ regulatory T cells in melatonin-mediated inhibition of murine gastric cancer cell growth in vivo and in vitro. Anat Rec (Hoboken) 2011; 294: 781-788. https://doi. org/10.1002/ar.21361 
[10] DUBOCOVICH ML, DELAGRANGE P, KRAUSE DN SUGDEN D, CARDINALI DP et al. International Union of Basic and Clinical Pharmacology. LXXV. Nomenclature, classification, and pharmacology of $\mathrm{G}$ protein-coupled melatonin receptors. Pharmacol Rev 2010; 62: 343-380. https:// doi.org/10.1124/pr.110.002832

[11] JABLONSKA K, PULA B, ZEMLA A, KOBIERZYCKI C, KEDZIA W et al. Expression of the MT1 melatonin receptor in ovarian cancer cells. Int J Mol Sci 2014; 15: 23074-23089. https://doi.org/10.3390/ijms151223074

[12] CARBAJO-PESCADOR S, GARCIA-PALOMO A, MARTIN-RENEDO J, PIVA M, GONZALEZ-GALLEGO J et al. Melatonin modulation of intracellular signaling pathways in hepatocarcinoma HepG2 cell line: role of the MT1 receptor. J Pineal Res 2011; 51: 463-471. https://doi.org/10.1111/j.1600079X.2011.00910.x

[13] SUNG JY, BAE JH, LEE JH, KIM YN, KIM DK. The Melatonin Signaling Pathway in a Long-Term Memory In Vitro Study. Molecules 2018; 23. https://doi.org/10.3390/molecules 23040737

[14] LEE S, JIN JX, TAWEECHAIPAISANKUL A, KIM GA, LEE BC. Stimulatory Effects of Melatonin on Porcine In Vitro Maturation Are Mediated by MT2 Receptor. Int J Mol Sci 2018; 19. https://doi.org/10.3390/ijms19061581

[15] ALTUN A, UGUR-ALTUN B. Melatonin: therapeutic and clinical utilization. Int J Clin Pract 2007; 61: 835-845. https:// doi.org/10.1111/j.1742-1241.2006.01191.x

[16] JOCKERS R, DELAGRANGE P, DUBOCOVICH ML, MARKUS RP, RENAULT $\mathrm{N}$ et al. Update on melatonin receptors: IUPHAR Review 20. Br J Pharmacol 2016; 173: 2702-2725. https://doi.org/10.1111/bph.13536

[17] EKMEKCIOGLU C. Melatonin receptors in humans: biological role and clinical relevance. Biomed Pharmacother 2006; 60: 97-108. https://doi.org/10.1016/j.biopha.2006.01.002

[18] DUBOCOVICH ML, MARKOWSKA M. Functional MT1 and MT2 melatonin receptors in mammals. Endocrine 2005; 27: 101-110. https://doi.org/10.1385/ENDO:27:2:101

[19] ZEMLA A, GRZEGOREK I, DZIEGIEL P, JABLONSKA K. Melatonin Synergizes the Chemotherapeutic Effect of Cisplatin in Ovarian Cancer Cells Independently of MT1 Melatonin Receptors. In Vivo 2017; 31: 801-809. https://doi. org/10.21873/invivo.11133

[20] LIU J, CLOUGH SJ, HUTCHINSON AJ, ADAMAH-BIASSI EB, POPOVSKA-GOREVSKI $M$ et al. MT1 and MT2 Melatonin Receptors: A Therapeutic Perspective. Annu Rev Pharmacol Toxicol 2016; 56: 361-383. https://doi.org/10.1146/ annurev-pharmtox-010814-124742
[21] MAO L, YUAN L, SLAKEY LM, JONES FE, BUROW ME et al. Inhibition of breast cancer cell invasion by melatonin is mediated through regulation of the p38 mitogen-activated protein kinase signaling pathway. Breast Cancer Res 2010; 12: R107. https://doi.org/10.1186/bcr2794

[22] NASRABADI NN, ATAEE R, ABEDIANKENARI S, SHOKRZADEH M, NAJAFI $M$ et al. Expression of MT2 receptor in patients with gastric adenocarcinoma and its relationship with clinicopathological features. J Gastrointest Cancer 2014; 45: 54-60. https://doi.org/10.1007/s12029013-9552-0

[23] NASRABADI NN, SARGAZI F, SHOKRZADEH M, ABEDIANKENARI S, HOSEINI SV et al. Expression of MT1 receptor in patients with gastric adenocarcinoma and its relationship with clinicopathological features. Neuro Endocrinol Lett 2018; 39: 111-118.

[24] MA L, WANG X, LAN F, YU Y, OUYANG X et al. Prognostic value of differential CCND1 expression in patients with resected gastric adenocarcinoma. Med Oncol 2015; 32: 338. https://doi.org/10.1007/s12032-014-0338-4

[25] KAWATA N, TSUCHIYA N, HORIKAWA Y, INOUE T, TSURUTA $\mathrm{H}$ et al. Two survivin polymorphisms are cooperatively associated with bladder cancer susceptibility. Int J Cancer 2011; 129: 1872-1880. https://doi.org/10.1002/ ijc. 25850

[26] SCHUSTER C. [Sites and mechanisms of action of melatonin in mammals: the MT1 and MT2 receptors]. J Soc Biol 2007; 201: 85-96. https://doi.org/10.1051/jbio:2007010

[27] DILLON DC, EASLEY SE, ASCH BB, CHENEY RT, BRYDON L et al. Differential expression of high-affinity melatonin receptors (MT1) in normal and malignant human breast tissue. Am J Clin Pathol 2002; 118: 451-458. https://doi. org/10.1309/1T4V-CT1G-UBJP-3EHP

[28] ZHAO M, WAN J, ZENG K, TONG M, LEE AC et al. The Reduction in Circulating Melatonin Level May Contribute to the Pathogenesis of Ovarian Cancer: A Retrospective Study. J Cancer 2016; 7: 831-836. https://doi.org/10.7150/ jca. 14573

[29] LISSONI P. Biochemotherapy with standard chemotherapies plus the pineal hormone melatonin in the treatment of advanced solid neoplasms. Pathol Biol (Paris) 2007; 55): 201-204. https://doi.org/10.1016/j.patbio.2006.12.025 